\title{
Erratum to: LAMP2 as a marker of EBV-mediated B lymphocyte transformation in the study of lysosomal storage diseases
}

\author{
A. S. Mello • M. P. Goldim • J. Mezzalira • \\ C. S. Garcia $\cdot$ V. V. Daitx $\cdot$ C. D. Castilhos · \\ M. S. Viegas $\cdot$ O. V. Vieira $\cdot$ J. C. Coelho
}

Published online: 18 October 2013

(C) Springer Science+Business Media New York 2013

Erratum to: Mol Cell Biochem

DOI 10.1007/s11010-013-1806-4

In the original article the name of one of the authors was incorrectly captured as: "V. V. Daitz"

His name should have been spelled as "V. V. Daitx".

Everything else in the paper remains correct.

The online version of the original article can be found under doi:10.1007/s11010-013-1806-4.

\footnotetext{
A. S. Mello $(\varangle) \cdot$ M. P. Goldim · J. Mezzalira .

C. S. Garcia - V. V. Daitx - C. D. Castilhos - J. C. Coelho Department of Biochemistry, ICBS-UFRGS, Federal University of Rio Grande do Sul, Rua: Ramiro Barcelos, 2600-anexo, Porto Alegre, RS 90035-003, Brazil

e-mail: melloas@gmail.com

M. S. Viegas - O. V. Vieira

Center for Neuroscience and Cell Biology, University of

Coimbra, Coimbra, Portugal
} 